\title{
Hepatitis Associated Aplastic Anemia (HAAA): A Rare Case of Severe Aplastic Anemia Following Acute Viral Hepatitis A
}

\author{
Bhatt $D^{1}$, Garg G' Gulati RK $^{3}$ \\ ${ }^{1}$ Dr. Dhaval Bhatt, PG Resident, Department Of Pediatrics, Govt. Medical College, Kota, ${ }^{2}$ Dr. Gaurav Garg, PG \\ Resident, Department Of Pediatrics, Govt. Medical College, Kota, ${ }^{3}$ Dr. R.K.Gulati, Senior Professor \& Head Of \\ Department, Department Of Pediatrics, Govt. Medical College, Kota, Rajasthan, India
}

Address for correspondence: Dr. Dhaval Bhatt, Email: dhavalbhatt89@gmail.com

\begin{abstract}
Hepatitis-associated aplastic anemia (HAAA) is acquired aplastic anemia in which marrow failure follows the development of hepatitis. HAAA was first described in 1955. It usually affects children and young adolescents. Immune mediated liver injury and bone marrow failure with involvement of activated lymphocytes may be proposed mechanism. We report a case of 17 year old female child who presented with fever, vomiting and yellow discoloration of urine with pallor and jaundice with pancytopenia. In our case report, Positive IgM Anti-HAV with aplastic bone marrow is found which is a rare association. Other viral markers are negative. Untreated HAAA has high mortality. HAAA has a very poor outcome. Management includes immunosuppression and anti-thymocyte globulin and ultimately bone marrow transplantation (BMT) may be required.
\end{abstract}

Keywords: HAAA, Hepatitis A, Aplastic Anemia

\section{Introduction}

Hepatitis associated aplastic anaemia (HAAA) is a syndrome of bone marrow failure occurring 2 to 3 months after an episode of acute hepatitis. [ 1,2,4 ] Moderate to severe aplastic anemia may occur after acute hepatitis. Onset of bone marrow failure is a bad prognostic sign in a patient with hepatitis who otherwise is recovering from the acute hepatic inflammation. The cause is uncertain and there is no known association with drugs/toxins, and blood transfusions. [2,3 ] Most of the patients are negative for markers of viral hepatitis. In our case IgM Anti-HAV is positive. Bone marrow aspiration suggests aplastic anemia. Acute viral hepatitis A induced aplastic anemia is a rare case $[1,2,4]$.

\section{Case Report}

We describe a case of a 17 year old female child, who presented at Department of pediatrics, J.K.Lon hospital, Kota with progressively increasing yellowish discoloration of urine \& eyes for 18 to 20 days'

Manuscript received: $22^{\text {nd }}$ March 2016

Reviewed: $04^{\text {th }}$ April 2016

Author Corrected; $15^{\text {th }}$ April 2016

Accepted for Publication: $28^{\text {th }}$ April 2016 duration. Fever for 2-3 days which was high grade, intermittent, without chills/rigor and no diurnal variation .Vomiting for 1 day, 4-5 episodes, nonbilious, non-projectile, no-blood stained vomitus. She had complaint of nausea, loss of appetite, easy fatigability and malaise. Parents denied any episodes of mental confusion and excessive sleepiness, as well as hematemesis and melena.

No history of abdominal pain, diarrhea, pale color stool. No history of itching. No history of tattooing \& blood transfusion in past. She denied any history of alcohol, tobacoo/smoking and drug use. There was past history of fever and jaundice before 3 months. For that she was not admitted, but symptom was relived by some oral medication. No family member is suffering with similar type of illness and/or chronic liver disorder.

On examination, severe pallor, icterus, tenderness on right hypochondrium, tender hepatomegaly $4.5 \mathrm{~cm}$ below right costal margin in mid-clavicular line without splenomegaly were found. Vitals are normal. No clinical signs of chronic/advanced liver disease. 
Laboratory Evaluation: Complete Blood Count (CBC) (Table 1), Peripheral Blood Smear, Liver Function Test (LFT) (Table 2), Viral markers (Table 3), Coagulation profile, PT/INR and Bone marrow aspiration was done.

Table 1: Complete Blood Count

\begin{tabular}{|l|l|l|l|l|l|l|}
\hline CBC & $\begin{array}{l}\text { WBC } \\
\text { (cells/cumm) }\end{array}$ & $\begin{array}{l}\text { RBC } \\
(\mathbf{m i l l i o n} \\
\text { cells/cumm) }\end{array}$ & $\begin{array}{l}\text { Hgb } \\
(\mathbf{g m} \%)\end{array}$ & $\begin{array}{l}\text { PLT } \\
\text { (cells/cumm) }\end{array}$ & $\begin{array}{l}\text { Neutophil } \\
\text { Count } \\
(\%)\end{array}$ & $\begin{array}{l}\text { ANC } \\
\text { (cells/cumm) }\end{array}$ \\
\hline Day 1 & 2350 & 1.12 & 3.2 & 3000 & 12 & 282 \\
\hline Day 2 & 1560 & 0.88 & 3.5 & 2000 & 16 & 240 \\
\hline Day 3 & 1700 & 1.53 & 5.5 & 4000 & 10 & 170 \\
\hline Day 4 & 1000 & 2.66 & 7.2 & 10000 & 19 & 190 \\
\hline
\end{tabular}

[WBC $=$ White Blood Cell, RBC=Red Blood Cell, Hgb= Haemoglobin, PLT=Platelets, ANC $=$ Absolute Neutophil Count], Peripheral blood smear analysis revealed pancytopenia with severe neutropenia \& severe thrombocytopenia and dimorphic anemia. Reticulocyte count was less than $1 \%$.

She underwent a bone marrow aspiration which showed severe hypocellular/aplastic bone marrow with dyserythropoiesis.

\section{Table 2: Liver Function Test (LFT) on day 1}

\begin{tabular}{|l|l|}
\hline Serum bilirubin ( Total ) & $8.7 \mathrm{mg} / \mathrm{dl}$ \\
\hline Alanine Aminotransferase (ALT) & $780 / \mathrm{dL}$ \\
\hline Aspartate Aminotransferase (AST) & $462 \mathrm{IU} / \mathrm{dL}$ \\
\hline Alkaline Phosphatase (ALP) & $58 \mathrm{U} / \mathrm{dL}$ \\
\hline Total protein & $4.6 \mathrm{gm} / \mathrm{dl}$ \\
\hline Serum Albumin & $1.3 \mathrm{gm} / \mathrm{dl}$ \\
\hline Serum Globulin & $1.3 \mathrm{gm} / \mathrm{dl}$ \\
\hline
\end{tabular}

\section{Table 3: Viral markers}

\begin{tabular}{|l|l|}
\hline Hepatitis A IgM & Positive \\
\hline Hepatitis B core IgM & Negative \\
\hline Hepatitis B surface antigen (HBsAg) & Negative \\
\hline Hepatitis C IgG antibody & Negative \\
\hline Anti-HEV antibody & Negative \\
\hline Anti-HAV antibody (total) & Positive $>$ 400IU \\
\hline HIV 1 \& 2 antibody & Negative \\
\hline Antinuclear antibodies & Negative \\
\hline
\end{tabular}

Coagulation profile and Prothombin Time (PT) / International Normalized Ratio (INR) was normal. Renal function Test was with in normal limits. Widal test, malarial parasite by card and dengue test was negative. Abdominal ultrasound and CT scan show fluid in peritoneal cavity with altered liver texture, but did not reveal any biliary obstruction.

Thus, Final Diagnosis was made as acute viral hepatitis A induced severe aplastic anemia. She was treated in PICU as per protocol with all supportive care. Blood transfusion and platelet transfusion was given. Danger sign of hepatic encephalopathy was closely monitored.

\section{Discussion}

Hepatitis associated aplastic anemia (HAAA) is a rare syndrome in which can complicate as moderate to severe aplastic anemia during recovery of acute hepatitis. [ 1,2 ] HAAA is caused by viral infections and idiopathic cases of acute hepatitis. However hepatitis A virus induced severe aplastic anemia is rare. 
Patients typically develop severe AA 2-3 months after an episode of acute hepatitis Clinically, acute hepatitis can be mild to fulminant and transient to persistent and precedes the onset severe aplastic anemia. [ 3,5 ] It is assumed that immunologic mechanism following acute viral hepatitis leads to the development of severe aplastic anemia. Severe aplastic anemia is defined as a condition in which 2 or more cell components have become seriously compromised (absolute neutrophil count $<500 / \mathrm{mm} 3$, platelet count $<20,000 / \mathrm{mm} 3$, reticulocyte count $<1 \%$ after correction for hematocrit) in a patient whose bone marrow biopsy material is moderately or severely hypocellular. [ 4 ] Prolonged pancytopenia can occur after infection with many of the hepatitis viruses. The hallmark of aplastic anemia is peripheral pancytopenia, coupled with hypoplastic or aplastic bone marrow. Leukopenia and thrombocytopenia due to bone marrow hypoplasia is a rare event in viral hepatitis. Immunosuppressive therapy, anti-thymocyte globulin and bone marrow transplantation (BMT) are available treatment modality $[5,6]$

\section{Conclusion}

HAAA is a well-defined clinical syndrome in which an attack of viral hepatitis A can also leads to bone marrow failure through immunologic mechanisms. Severe aplastic anaemia is a rare complication of hepatitis A and the outcome is very poor if untreated. Overall prognosis is poor. Management includes immunosuppression, anti-thymocyte globulin and ultimately bone marrow transplantation. In our case report, we are able to identify the rare case of Acute Viral Hepatitis A induced and/or complicated by severe aplastic anaemia.

\section{Source of Support: Nil, Conflict of Interest: None Permission of IRB: Yes}

\section{References}

1. Brown KE, Tisdale J, Barrett AJ, Dunbar CE, Young NS. Hepatitis-associated aplastic anemia. N Engl J Med. 1997 Apr 10;336(15):1059-64.

2. Hepatitis associated aplastic anemia D Shenoy, N Pai, Journal, Indian Academy of Clinical Medicine Vol. 3, No. 1 _ January-March 2002.

3. Young NS, Issaragrasil S, Chieh CW, Takaku F. Aplastic anaemia in the Orient. Br J Haematol. 1986 Jan;62(1):1-6.

4. Systematic review: hepatitis-associated aplastic anaemia -a syndrome associated with abnormal immunological function .R. GONZALEZ-CASAS, L. GARCIA-BUEY, E. A. JONES. Aliment Pharmacol Ther 30, 436-443, 2009.

5. Severe Aplastic Anemia following Acute Hepatitis from Toxic Liver Injury: Literature Review and Case Report of a Successful Outcome. Kamran Qureshi, Hicham Khallafi. Case Reports in Hepatology Volume 2014 (2014), Article ID 216570, 7 pages

6. SEVERE APLASTIC ANEMIA AND SERONEGATIVE AUTOIMMUNE HEPATITIS: A CONCURRENCE OR CONSEQUENCE? AMERICAN SOCIETY OF HEMATOLOGY HTTP://WWW.BLOODJOURNAL.ORG/CONTENT/124/ 21/5153.E-LETTERS

\section{How to cite this article?}

Bhatt D, Garg G, Gulati RK. Hepatitis Associated Aplastic Anemia (HAAA): A Rare Case of Severe Aplastic Anemia Following Acute Viral Hepatitis A: Int J Pediatr Res 2016;3(4):260-262.doi:10.17511/ijpr.2016.i04.09. 